\section{Mr. E. R. Gunther}

IT is barely two months since NATURE regretted the passing of Dr. R. T. Gunther; now comes the untimely death of his eldest son, Eustace Rolfe Gunther, at the age of thirty-seven, accidentally shot while on active service. This tragic event robs oceanography of one of the most virile of its younger workers. Educated at Winchester and Caius College, Cambridge, he was appointed as zoologist in 1924 to be one of the original members of the scientific staff of the Discovery Committee set up by the Colonial Office to investigate the resources of the antarctic seas, particularly in regard to the factors, biological and physical, governing the great whale fisheries of those waters.

It was my privilege to be closely associated with Gunther on the R.R.S. Discovery on her voyage of 1925-27, on the smaller ship R.R.S. William Scoresby, and afterwards in the joint authorship of an extensive report upon the ecology of the antarctic plankton. $\mathrm{He}$ was a man of sterling qualities. Working with him day and night, often under the difficult conditions presented by the Southern Ocean, one was continually impressed by his deep sense of duty, his devotion to his work, and his tireless energy. His enthusiasm was always combined with a scrupulous regard for accuracy: both in the field and the working-up of data. After working at the nets and water-bottles for thirty-six hours on end, except for odd moments snatched for hurried meals, it was only the fear of being inaccurate in the readings and recordings, not fatigue itself, which persuaded him to rest. He had a love of the sea and the open life ; he was a real deep-water oceanographer, with the determination to bring back results.

In 1931 on the R.R.S. William Scoresby, Gunther led a highly successful expedition to investigate the Peru Coastal Current (sometimes called Humboldt's Current) and published in 1936 a comprehensive report on its physical, chemical and biological aspects. Later he again visited the Antaretic on a whalemarking expedition to study migrations, and made valuable observations on the swimming and breathing habits of whales (a paper now in the press). Much of his time before the War was spent in working on the material collected during a trawling survey, partly carried out under his direction, on the extensive banks lying between the Falkland Islands and South America. It is to be hoped that all the work he put into this will eventually be published.

In addition to his wide interests in zoology and oceanography, Gunther was always delighted to record any unusual natural phenomenon; his recent letter in NATURE on the ice storm in Wiltshire is an example of this. Colour and scenery were a great joy to him, and he did splendid water-colour drawings, both sea and landscape, as well as accurate colour studies of marine animals. Many will treasure his privately printed "Notes and Sketches made during two years on the Discovery Expedition".

It was characteristic of Gunther's capacity for work that his long leave after the 1925-27 expedition should have been spent in the Department of Bio- chemistry at Cambridge, undertaking researches on the fatty and vitamin content of plankton (published in collaboration with G. Collin, J. C. Drummond and T. P. Hilditch). His published work, while extensive, is no real measure of his industry. He was always being attracted by side branches which he felt it his duty to explore, and only when he had carried them a long way did he realize he was being taken too far from the main issue; reluctantly they were put on one side for some later available time-alas, now no more.

In 1937, distressed by Great Britain's unpreparedness for war, Gunther joined the territorials as a sapper and was commissioned a year later. On inquiry about the best use a man of his training might be, he was advised to enter the searchlight service, and his keen powers of observation were of particular use in training spotters. He was born on September 20, 1902. In 1929 he married Dr. Mavis Carr and leaves a son and two daughters. $\mathrm{He}$ was essentially happy in his work and family life, and was devoted to both. He has been a worthy upholder of the tradition set by his father, his grandfather, Dr. A. G. L. G. Gunther, F.R.S., and his great-uncle, Prof. W. C. MeIntosh, F.R.S.

A. C. Hardy.

\section{Dr. Wilhelm Stekel}

Dr. WILHELM STEKEL, the well-known psychoanalyst of Vienna, who died in London on June 27, was born at Bojan in Bukowina on March 18, 1868. He received his medical education in Vienna, where he was one of Krafft-Ebing's pupils, and qualified in 1893. After some years general practice he devoted himself entirely to neurology and psychiatry. He was one of the first medical men to be interested in psychoanalysis, and from 1896 until 1912 when, like Adler, Breuer and Jung, he assumed his independence, he was one of Freud's chief supporters. He was a very prolific writer. His principal works, which were all translated into English, are "The Beloved Ego" (1921), "Psychoanalysis and Suggestion Therapy" (1923), "Peculiarities of Behaviour" (1924), "Disorders of the Instincts and Emotions" (1929-1930), and "The Homosexual Neurosis" (1933). From 1910 until 1913 he was coeditor with Freud and Adler of the Zeitschrift für Psychoanalyse, and in 1924 became editor of Fortschritte der Sexualwissenschaft und Psychoanalyse.

WE regret to announce the following deaths :

Prof. J. G. Dusser de Barenne, Sterling professor of physiology in Yale University, on June 9, aged fifty-five.

Mr. C. Rawson, head chemist of the British Cotton and Wool Dyers' Association during 1917-20, aged eighty-one.

Prof. D. Riesman, professor of the history of medicine in the University of Pennsylvania, on June 3, aged seventy-three. 